\title{
Effective Process Conditions and Reactor Design Parameters for Oil Separation by Electrocoagulation
}

\author{
S. L. J. Wijeyekoon, R. A. K. P. Abeysinghe, U. Karunaratne and M. W. Jayaweera
}

\begin{abstract}
Thermal power generating plants, service stations and oil refineries generate oily wastewaters which are recognized to be a severe threat to aquatic environments. Electrocoagulation has received considerable attention lately as a clean technology option yet absence of reactor design criteria and scientific understanding of the complex phenomena involved remain as a drawback to its widespread application. Laboratory experiments were conducted to determine the optimum operating parameters such as electrode type, influent $\mathrm{pH}$, initial oil concentration, electrode polarity change, electrode surface area: reactor volume, current density and electrode spacing on COD removal efficiency. The effective $\mathrm{pH}$ for oil removal is dependent on the anode material used. A pH of 4 is suitable when $\mathrm{Al}$ is used where as the effect of $\mathrm{pH}$ is negligible for iron electrodes. High removal efficiencies are obtained for moderate oil concentrations of $400-500 \mathrm{mg} / 1$ as COD. The optimum current density and electrode surface area to volume ratio were $46.9 \mathrm{~A} / \mathrm{m} 2$ and $8.5 \mathrm{~m}^{2} / \mathrm{m}^{3}$ respectively. The electrode polarity switch leads to rapid dissolution of the electrodes and improved COD removal efficiency. The developed design parameters enable the design of low cost compact treatment units that could be powered by DC sources for effective oil separation from wastewaters.
\end{abstract}

Keywords: Current density, electrocoagulation, electrode spacing, oil separation

\section{Introduction}

Industries such as edible and crude oil refineries, petrochemical and thermal power generation plants, service stations, restaurants etc. produce oily wastewaters that are recognized to be a formidable challenge to treat and constitute a major threat to the local environments and eco systems. In thermal power plants the oily wastewater is generated in heavy fuel oil separators, machine shop, from steam cleaning in workshops, radiator cleaning, from fuel unloading by road tankers and during cleaning of engine parts. In garages, dismantling of engines and removal of used oil from the engines are the main sources of waste oil generation. In addition, waste oil is generated from repairs to crankcase, gearbox, brakes and such other parts of vehicles. Leaking flanges, pumps, storage tanks, filling and decanting operations in refineries, food preparation and cleaning operations in both small and large restaurants generate oily wastewaters. Varying concentration of hydrocarbons are common constituents in industrial wastewaters and can be found as free floating, emulsified, dissolved or absorbed to suspended solids. Effluents with waste oil cause both surface and ground water pollution leading to destruction of sensitive eco systems and contamination of drinking water sources. The resulting effects on the environment include; impact on fish populations, destruction of phyto-planktons and on aesthetic quality of receiving water bodies. Further effluents discharged to crop fields badly affect soil permeability and hence crop productivity.

The majority of oil and grease removal technologies are physical separation unit operations that make use of the difference in density of water and oil. However oils and fats are partly soluble in water and are present in separable, dissolved and emulsified states. Most of the technologies used remove only the separable fraction of oils and fats and therefore has only a limited effect in reducing the COD

Eng. (Dr.) S.L.J. Wijeyekoon, B.Sc. Eng. (Hons) (Moratuwa),M.Eng. (Tokyo), PhD (Tokyo), C. Eng., MIESL, Senior Lecturer in Environmental Engineering attached to the Department of Chemical and Process Engineering, University of Moratuwa. He is a consultant in thefields of Environmental Management, Cleaner Production and Sustainable Environmental Technologies.

Eng.(Miss) R.A.K.P.Abeysingke, B.Sc. Eng. (Hons) (Moratuwa), AMIE(SL), Postgraduate student attached to the Division of Environmental Engineering, Department of Civil Engineering, University of Moratuwa.

U. Karunaratne, BSc (Kalaniya),MSc (Moratuwa), currentlyemployed at Caterpillar Power Generation Systems LLC, EmbilipitiyaPower Plant. Eng. (Dr.) M.W. Jayaweera B.Sc. Eng. (Hons). (Moratuwa), PhD. Saitama University, Japan, C. Eng., MIESL is a Senior Lecturer in Environmental Engineering at the Department of Civil Engineering, University of Moratuwa. Hehas considerable experience in environmental management andpollution control. 
load from such wastewaters. Further, majority of the oil and grease sources are either small and medium scale industries or small service sector entities that are located in highly urbanized or residential areas releasing small quantities of wastewater that do not require an Environmental Protection Licence (EPL) to operate. They do not have the financial capability to invest in wastewater treatment plants (WWTP) nor have the technical capacity to operate and maintain WWTP and neither have space to locate treatment units. Therefore an efficient, cost effective, compact treatment unit that do not require pre or post treatment with simple maintenance requirements needs to be developed for treatment of wastewaters from such facilities. [21]

There are several methods currently practiced in many industries to remove oil and grease from wastewater. The most widely used methods for free oil separation are; API and CPI separators, three chamber pits with skimming, fat traps, dissolved air flotation, filtration and chemical coagulation. However conventional technology options for oil and grease removal are capital intensive, require larger foot print, are less efficient and need frequent operation and maintenance when considerable presence of emulsified oil is encountered.

In recent years, new and novel processes for efficient and adequate treatment of various industrial wastewaters with relatively low operating costs have been explored due to strict environmental regulations. Electrocoagulation (EC) process has attracted a great deal of attention lately in treating industrial wastewaters because of its versatility and low secondary environmental impact. This technique has certain advantages when compared to conventional methods such as simple equipment with no moving parts, ease of operation, less retention time and therefore small foot print, absence of external chemical addition with ancillary dosing equipment, rapid sedimentation of the electrogenerated flocs, less sludge production and safe operation due to the low voltage applied. EC could be used as an effective and reliable method for reducing or removing a large variety of pollutants in wastewaters. [16] Electro-coagulation has been proved to be an efficient treatment method for multitude of wastewaters. The technology has been successfully used to treat the wastewaters of textile $[7,30]$, oil wastewater $[4,6,18,27,28]$, restaurant wastewater $[8,11]$ and slaughter house effluent $[17,19]$. It is particularly more effective in treating wastewaters containing small and light suspended particles (e.g. oily wastewater) because of the accompanying electro-flotation effect. Moreover, and perhaps most importantly, during EC the liquid is not enriched with anions, and its salt content does not increase, as is the case with chemical treatment [21].

It is reported that the EC efficiency is generally high for oily wastewaters [3]. In most applications reported, aluminium or iron are used as electrode materials. EC has a long history as a wastewater treatment unit. However EC has never become accepted as a mainstream wastewater treatment technology. The lack of systematic approach to EC reactor operation and the issue of electrode reliability have limited its implementation. Nevertheless recent technological improvements combined with a growing need for small-scale decentralized wastewater treatment facilities have lead to re-evaluation of electro coagulation as an appropriate technology [12]. Due to the complex interaction of physical and electrochemical processes and to the conflicting and confusing process and design parameters reported, there is a compelling need for reevaluation of the important parameters for rational elucidation of results and for design of EC cells prior to the industrial application.

A simple electrocoagulating reactor is made up of one anode and one cathode. When a potential is applied from an external power source, the anode material undergoes oxidation, while the cathode will be subjected to reduction or reductive deposition of elemental metals [20].

The scope of this study was limited to laboratory scale, batch reactor operation for separating the effects of various process parameters such as electrode type, influent $\mathrm{pH}$, initial oil concentration and current density on oil removal efficiency, to develop reactor cell design criteria for electrode surface area: reactor volume, electrode spacing and to determine the effect of electrode polarity switch on efficiency and electrode dissolution. 


\section{Materials and Methods}

\subsection{Effect of initial $\mathrm{pH}$}

The EC was carried out in a beaker of $40 \mathrm{~mm}$ diameter and $60 \mathrm{~mm}$ deep and having a capacity of $50 \mathrm{ml}$. Aluminium thin plate of size $(0.23 \mathrm{x}$ $10.75 \times 77.00) \mathrm{mm}$ was used as anode and cathode. The plates were washed with distilled water and then immersed to a depth of $32 \mathrm{~mm}$ in the prepared wastewater. The electrode distance was $26 \mathrm{~mm}$. A variable voltage DC power supply was connected to the circuit consisting of an electrolyte, a precision type milliammeter, and an adjustable resistance in series and a voltmeter connected across the electrodes in the bath. Seven numbers of synthetic wastewater samples were used by adjusting the sample $\mathrm{pH}$ with either $\mathrm{HCl}$ or $\mathrm{NaOH}$ to a value of $2.33,3.88,3.906 .28,8.04$, $10.12,12.02$ with an initial COD of $290 \mathrm{mg} / \mathrm{L}$. The sample size was $40 \mathrm{ml}$ with 30 minute electrolysis duration at the applied current density of $50.7 \mathrm{~A} / \mathrm{m}^{2}$.

\subsection{Effect of initial concentration}

The EC cell consisted of a glass beaker of diameter $127 \mathrm{~mm}$ and $180 \mathrm{~mm}$ depth having a capacity of $250 \mathrm{ml}$ (Figure 1). Aluminium thin plates of size $(0.60 \times 21.20 \times 90.00) \mathrm{mm}$ were used as anode and cathode. The plates were washed with distilled water and then immersed to a depth of $50 \mathrm{~mm}$ in the synthetic wastewater. $0.185 \mathrm{~g}$ of $\mathrm{NaCl}$ was added into $200 \mathrm{ml}$ of wastewater to improve the conductivity of the solution. The electrode distance was set at 20

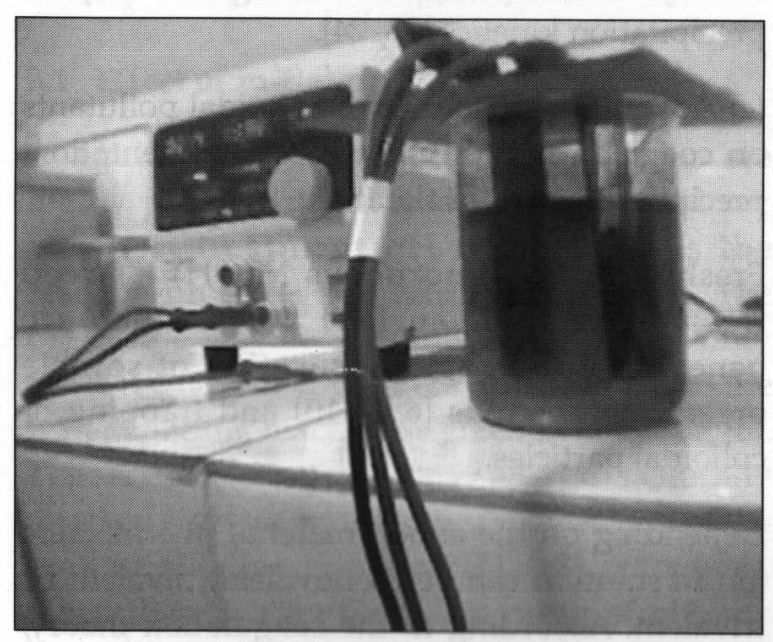

Figure 1. The electrocoagulation cell with variable DC power supply $\mathrm{mm}$. The circuit and electrolysis duration was as same as described in 2.1. Eight no of synthetic wastewater samples with initial COD of 66,95 , $104,152,238,292,333$ and $419 \mathrm{mg} / \mathrm{L}$ were used with an applied current density of $100 \mathrm{~A} / \mathrm{m}^{2}$.

\subsection{Effect of current density}

The EC cell configuration and the operation were as same as described in 2.2 above. The applied current through the $200 \mathrm{ml}$ oily water solutions were $0.05,0.1,0.2,0.3,0.4,0.5,0.6,0.8$, and 1.0 amperes and samples were taken for analysis after 30 minutes of electrolysis.

\subsection{Effect of electrode material}

The EC cell circuit was as same as described in 2.2 above. Aluminium and carbon plates of size $(5.15 \times 22.56 \times 93.00) \mathrm{mm}$ were used as electrodes in combinations as given in Table 1 below. The plates were washed with distilled water and then immersed to a depth of $52 \mathrm{~mm}$ in wastewater collected from thermal power plant oily water separator outlet. $0.185 \mathrm{~g}$ of $\mathrm{NaCl}$ was added into $200 \mathrm{ml}$ of sample to improve electrical conductivity. The electrode distance was $20 \mathrm{~mm}$ with 0.001 (A) current applied through the oily wastewater having an initial COD of $305.9 \mathrm{mg} / 1$.

Table 1. Electrode material combinations used

\begin{tabular}{|c|l|l|}
\hline Run \# & Cathode & Anode \\
\hline 1 & Aluminum & Aluminum \\
\hline 2 & Aluminum & Carbon \\
\hline 3 & Carbon & Aluminum \\
\hline 4 & Carbon & Carbon \\
\hline
\end{tabular}

\subsection{Effect of electrode polarity switching on COD removal efficiency}

The EC cell was setup as above with aluminium thin plates as electrodes with $17 \mathrm{~cm} 2$ active area and reactor volume of $1000 \mathrm{ml}$. Initial $\mathrm{pH}$, initial COD and initial conductivity of the synthetic wastewater were $7.25,514.5 \mathrm{mg} / \mathrm{L}$ and $640 \mu \mathrm{S}$ respectively. The electrode distance was $10 \mathrm{~mm}$. The applied current through the oily water solution was 0.2 (A) and the voltage was controlled at $30 \mathrm{~V}$.

Electrocoagulation test runs were carried out by changing the electrode polarity during each 10 minute operation. Samples were taken at the end of each 20 minutes experimentation time 
duration for COD analysis. A control experiment was also carried out without polarity change.

\subsection{Effect of the variation of reactor volume to electrode surface area}

Electrocoagulation test runs were carried out by changing the reactor volume for a fixed electrode surface area. Aluminium thin plates were used as anode and cathode with $25.4 \mathrm{~cm}^{2}$ active area. Initial $\mathrm{pH}$ and initial conductivity of the synthetic wastewater were 6.65 and $640-700$ $\mu \mathrm{S}$ respectively. The electrode distance was 10 $\mathrm{mm}$. The applied current through the oily water solution was $0.2(\mathrm{~A})$ and voltage was controlled at $12 \mathrm{~V}$.

\subsection{Effect of electrode spacing on COD removal efficiency}

Aluminium thin plates were used as anode and cathode with $25.4 \mathrm{~cm} 2$ active area. Initial $\mathrm{pH}$ and initial conductivity of the synthetic wastewater were 7.4 and $727 \mu \mathrm{S}$ respectively. The reactor volume was $300 \mathrm{ml}$. The applied current through the oily water solution was 0.2 (A) and voltage was controlled at $12 \mathrm{~V}$.

Electro-coagulation test runs were carried out by changing the electrode spacing in the range of 5 to $40 \mathrm{~mm}$. The COD was tested in samples withdrawn at the end of each 20 minutes experimentation time duration.

\subsection{Analytical procedures}

The COD was analysed according to Standard Methods [1] by the reflux method. Initial samples were taken after homogenization of the added predetermined quantity of oil into the synthetic wastewater solutions. In instances where real wastewater was used, samples were homogenized to disrupt the phase separation by vigorous shaking prior to sampling for analysis. Samples for COD analysis after electrolysis were withdrawn by a pipet, by carefully avoiding the top surface oil film and the settled sludge at the bottom of the beaker. The $\mathrm{pH}$ of the solutions were adjusted either by $0.5 \mathrm{M} \mathrm{HCl}$ or $1 \mathrm{M} \mathrm{NaOH}$ and measured using a HANNA pH 211 microprocessor $\mathrm{pH}$ meter. The conductivity was measured by CON 510 bench conductivity meter made in Singapore.

\subsection{Instrumentation used for the experimental setup}

A regulated DC power supplier (Protek dual DC power supply 3015B), that could operate in constant current $(0-1.5 \mathrm{~A})$ or constant voltage $(0-$ $30 \mathrm{~V})$, was used to power the electro coagulation unit.

\section{Results and Discussion}

Oil and grease can be separated from wastewater by coagulation, flotation, gravity separation, membrane separation, absorption, adsorption, filtration and by the application of heat and/or chemicals for emulsion destabilization. In electrocoagulation, wastewater purification occurs primarily due to coagulation, flotation and generation of heat.

Main processes which occur during EC are as follows:

(a) Electrolytic reactions at electrode surfaces:

Anode:

$\mathrm{M} \longrightarrow \mathrm{M}^{\mathrm{n}+}{ }_{(\mathrm{aq})}+\mathrm{ne}$

Cathode:

$\mathrm{nH}_{2} \mathrm{O}+\mathrm{ne} \longrightarrow(\mathrm{n} / 2) \mathrm{H}_{2}+\mathrm{nOH}^{-}$

where $\mathrm{M}$ is metal ion.

(b) The formation of coagulants in aqueous phase:

$\mathrm{M}^{3+}{ }_{\text {(aq) }}$ and $\mathrm{OH}$ - ions generated by electrode reactions (1) and (2) react to form various hydroxo monomeric and polymeric species, depending on $\mathrm{pH}$ range, which transform finally into $\mathrm{M}(\mathrm{OH})_{\mathrm{n}}$ according to complex precipitation kinetics [23, 24].

(c) Adsorption of soluble or colloidal pollutants on coagulants, and removal by sedimentation, precipitation and/or flotation:

Freshly formed amorphous $\mathrm{M}(\mathrm{OH})_{\mathrm{n}}$ "sweep flocs" have large surface areas which are beneficial for a rapid adsorption of soluble organic compounds $[6,8,10]$ and trapping of colloidal particles.

Depending on the anode material, the metallic ion in solution can be monovalent, divalent or trivalent. According to the coagulation theory, the efficacy of coagulation increases and the 
amount of coagulant (metallic cations) required decreases with the increasing valency of the metal ion in solution. The metal ion hydrolyses and forms complex metallic flocs that are responsible for adsorption of oil and sweeping of emulsified oil droplets from the wastewater. The simplified overall reactions can be represented as follows:

$$
\begin{aligned}
& \mathrm{M}^{+\mathrm{n}}{ }_{(\mathrm{aq})}+\mathrm{nH}_{2} \mathrm{O} \longrightarrow \mathrm{M}(\mathrm{OH})_{\mathrm{n}_{(\mathrm{aq})}}+\mathrm{nH}^{+}{ }_{(\mathrm{aq})} \ldots \\
& \mathrm{xM}(\mathrm{OH})_{\mathrm{n}(\mathrm{aq})} \longrightarrow \mathrm{M}(\mathrm{OH})_{\mathrm{n}} \mathrm{x}_{(\mathrm{aq})}
\end{aligned}
$$

The electrons released at the anode can electrolyse water and precipitate cations in solution. Electrolysis of water molecule at the cathode results in the evolving of hydrogen gas as shown in (2), that aid in the flotation of oil to the surface. The $\mathrm{NaCl}$ added to improve the conductivity of electrolyte can precipitate at the cathode as shown in equation (5).

$\mathrm{Na}^{+}+\mathrm{e}^{-} \longrightarrow \mathrm{Na}_{(\mathrm{s})}$

The following half reactions at the anode that evolve oxygen and chlorine gas also aid in the electroflotation of oil.

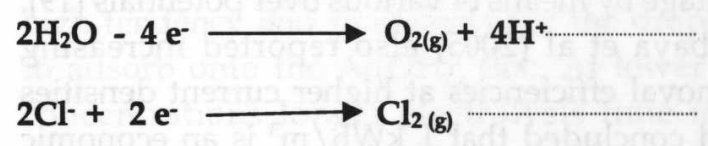

Further, the splitting of water at high applied voltage results in the heating up of the solution that also aid in the breaking of oil emulsions. However heating and water splitting is considered energy inefficient, and the low voltages applied in this study does not make this mechanism of oil removal a significant one. Once the emulsion is broken, the oil droplets can either coagulate or float to the surface and thereby be separated from the bulk solution.

\subsection{Effect of initial $\mathrm{pH}$}

Coagulation and precipitation reactions are highly $\mathrm{pH}$ dependent and therefore need pre and post treatment $\mathrm{pH}$ adjustment as the reaction products also affect the final $\mathrm{pH}$. The $\mathrm{pH}$ of the wastewater solution will not only affect the type of complexes formed but also the water splitting reaction as given in equation (6). The sacrificial electrodes may also be chemically attacked by $\mathrm{H}+$ ions in acidic medium or by $\mathrm{OH}-$ ions in alkaline medium [11, 22]. However, when there is significant buffering of $\mathrm{pH}$, the effect of $\mathrm{pH}$ on the electrochemical reactions is less pronounced.
The $\mathrm{pH}$ of the initial wastewater solution was varied in the range $2-12$ by adding $1 \mathrm{M} \mathrm{NaOH}$ or $0.5 \mathrm{M} \mathrm{HCl}$ to investigate its effect on the COD removal efficiency. Figure 2 shows the removal efficiencies of COD as a function of the initial $\mathrm{pH}$. At the extreme $\mathrm{pH}$ of 2 and 12, the COD removal efficiency is drastically decreased. Between $\mathrm{pH}$ of 4 and 10, decreasing removal efficiency is shown with increasing $\mathrm{pH}$. Similar variation is reported in [19] for aluminium electrodes. The effect of $\mathrm{pH}$ on $\mathrm{COD}$ and oil and grease removal is negligible when iron electrodes are used [28]. If $\mathrm{pH}$ variation of the wastewater is significant or in the alkaline range, aluminium as an electrode material may not be a suitable option. However most industrial oily wastewaters lie in the $\mathrm{pH}$ range of 5.6-8.8 and therefore pre $\mathrm{pH}$ adjustments may not be required for most industrial wastewaters treated by EC.

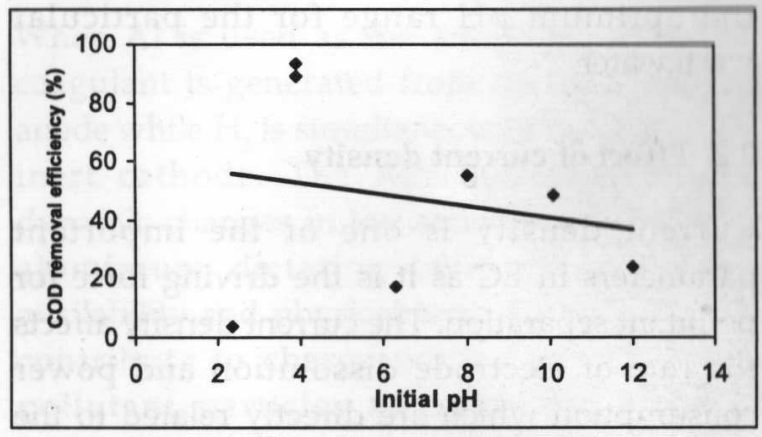

Figure 2: The effect of influent $\mathrm{pH}$ on COD removal efficiency

The EC reactions with aluminium electrode are similar to the chemical coagulation reactions using alum as the coagulant. Electrolytic dissolution of aluminium anode produce the $\mathrm{Al}^{+3}$ and $\mathrm{Al}(\mathrm{OH}) 3+$ ions and complexes at low $\mathrm{pH}$ and finally $\mathrm{Aln}(\mathrm{OH})_{3 \mathrm{n}}$ as shown in equation (1), (3) and (4).

The formed aluminium polymer will settle with pollutant oil particles by adsorption and charge neutralization. Both processes rely mainly on various aluminium intermediate products formed during hydrolysis of $\mathrm{Al}^{+3}$. It has been reported that this is achieved at $\mathrm{pH} 5.0-6.0$ according to the following reactions [8]. At alkaline solution $\mathrm{pH}$, the cathode and anode reactions respectively are:

$$
\begin{aligned}
& \mathrm{Al}_{(\mathrm{S})}+4 \mathrm{OH}^{-}=\left[\mathrm{Al}(\mathrm{OH})_{4}\right]^{-}+3 \mathrm{e}^{-} \\
& 4 \mathrm{OH}^{-}-4 \mathrm{e}^{-}=2 \mathrm{H}_{2} \mathrm{O}+\mathrm{O}_{2(\mathrm{~g})}
\end{aligned}
$$


At acidic solution $\mathrm{pH}$, the cathode and anode reactions respectively are:

$2 \mathrm{HO}_{3}{ }^{+}+2 \mathrm{e}=\mathrm{H}_{2}(\mathrm{~g})+2 \mathrm{H}_{2} \mathrm{O}$

and anode reaction;

$\mathrm{Al}_{(\mathrm{s})}-3 \mathrm{e}=\mathrm{Al}_{(\mathrm{aq})}$

The decrease of COD removal at $\mathrm{pH}<2$ and $>12$ was probably due to less $\mathrm{Al}(\mathrm{OH})_{3}$ floc formation. The $\mathrm{Al}(\mathrm{OH})_{3}$ gelatinous floc is thought to be responsible for the removal of soluble COD by adsorption. The optimum $\mathrm{pH}$ for alum coagulation lies between 5.5 and 6.5 . At low $\mathrm{pH}$, due to the hydrogen gas bubbling, enhanced removal is possible due to both coagulation and flotation mechanisms. A high COD removal efficiency of $93.1 \%$ was obtained at $\mathrm{pH} 4$ due to this dual effect. As the alkalinity and buffering capacity of each wastewater is different, when aluminium electrodes are used, a simple $\mathrm{pH}$ effect study would help determine the optimum $\mathrm{pH}$ range for the particular wastewater.

\subsection{Effect of current density}

Current density is one of the important parameters in EC as it is the driving force for pollutant separation. The current density affects the rate of electrode dissolution and power consumption which are directly related to the efficiency and economics of the process. As the efficiency and treatment costs are inversely related, optimum current density is dictated by the level of treatment required and the affordable cost of treatment desired.

Figure 3 represents the effect of current density on COD removal efficiency with a 30 minute operating time. The data exhibit significant scatter with greater than $90 \%$.COD removal efficiencies at both low and high current densities applied. The best efficiencies were obtained ( $100 \%$ COD removal efficiency) for current densities of $46.9,140.7,187.5$ and 468.9 $\mathrm{A} / \mathrm{m} 2$ at the initial concentration of $122-292$ $\mathrm{mg} / \mathrm{L}$ used. This suggests that the smaller current densities applied are sufficient for the separation of the oil and the higher current densities used constitute a power wastage.

At high current densities, the temperature of the electrolytic solution increases as the resistance builds up due to ion migration and depletion. Further, the high rate of gas evolution at high

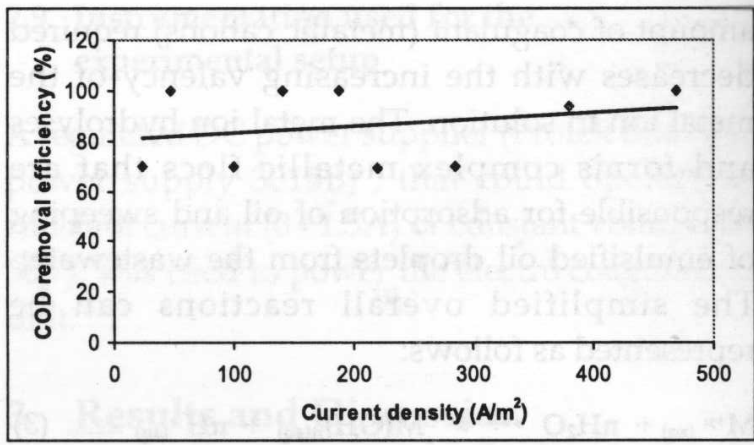

Figure 3: The effect of current density on COD removal efficiency

current densities disturbs the sedimentation and impedes settling of the flocs. With the cell configuration used, the optimal current density was $46.9 \mathrm{~A} / \mathrm{m}^{2}$ considering higher COD removal efficiency and low power consumption.

The current densities were changed from 23.4 $\mathrm{A} / \mathrm{m}^{2}$ to $468.9 \mathrm{~A} / \mathrm{m}^{2}$ which result in power consumption of $0.75 \mathrm{kWh} / \mathrm{m} 3$ to $15 \mathrm{kWh} / \mathrm{m}^{3}$. The electrical energy consumption increases nonlinearly with increasing current density due to strong impact of current density on cell voltage by means of various over potentials [19]. Kobaya et al (2005) also reported increasing removal efficiencies at higher current densities and concluded that $1 \mathrm{kWh} / \mathrm{m}^{3}$ is an economic power consumption with a current density of below $125 \mathrm{~A} / \mathrm{m}^{2}$. Xu and $\mathrm{Zhu}$ (2004) concluded that for the reactor configuration used, the optimum current density was in the range of 10 - $14 \mathrm{~A} / \mathrm{m}^{2}$ with a power consumption of 0.60 $0.84 \mathrm{kWh} / \mathrm{m}^{3}$. It is clear that the current density and the power consumption are largely dependent on the cell configuration used and therefore improved cell configurations would further improve the efficiency and cost of treatment.

\subsection{Effect of initial oil concentration}

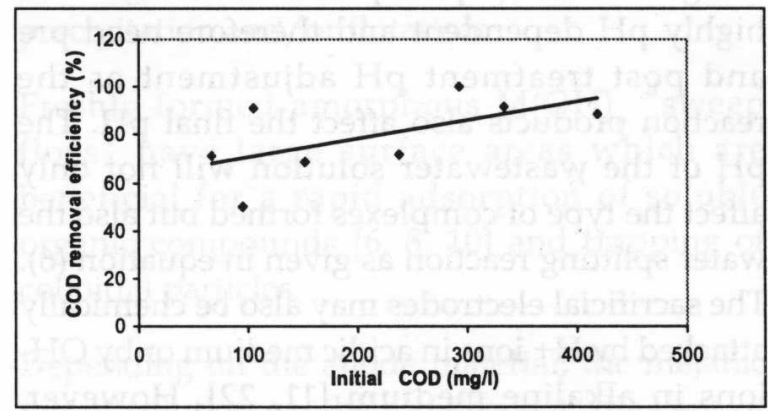

Figure 4: The effect of initial COD on COD removal efficiency 
Oil concentration in industrial wastewater can vary from a few $\mathrm{mg} / \mathrm{L}$ up to $5000 \mathrm{mg} / \mathrm{L}$ as COD. The concentration of oily wastewater from thermal power plants fluctuate between $66 \mathrm{mg} /$ $\mathrm{L}$ to $1080 \mathrm{mg} / \mathrm{L}$ as COD and in most instances was found to be below $500 \mathrm{mg} / \mathrm{L}$. No single technology would have the same efficiency of removal for such a wide range of oil concentration. Efficiency of removal is technology and initial concentration dependent. Very low initial concentrations are difficult to remove and hence efficiencies of removal are lower. On the other hand, high initial concentrations enhance separation depending on the driving force applied and will "underperform" when moderate concentrations are encountered.

Figure 4 shows the COD removal efficiencies at different initial COD concentrations when the current density was $46.9 \mathrm{~A} / \mathrm{m}^{2}$. Removal efficiencies above $50 \%$ were obtained with higher efficiencies at high concentrations. At higher concentrations the oil emulsion droplets are closely dispersed and therefore there is a high tendency and probability for the droplets to adsorb onto the $\mathrm{Al}(\mathrm{OH})_{3}$ floc. At lower oil concentrations longer electrolysis time may improve the removal efficiency. The results show that an efficiency greater than $90 \%$ could be achieved when COD concentration above 300 $\mathrm{mg} / \mathrm{L}$.

\subsection{Effect of electrode material}

Different electrode materials and material combinations can be used for electrocoagulation of wastewater. $\mathrm{Al}-\mathrm{Al}[7,9,15,18], \mathrm{Al}-\mathrm{Fe}[5,12$, $17,19,29], \mathrm{Fe}-\mathrm{Fe}[13,25,28,30]$ electrodes have been used for different type of wastewaters. Depending on the electrode material used, the cation responsible for coagulation, the effective $\mathrm{pH}$ of coagulation, the gas bubble size, the final quality of the water produced and the cost of electrode replacement and the chemical and electrochemical reactions involved are different and will affect the performance and economics of the process. $\mathrm{Al}$ and $\mathrm{Fe}$ electrodes are commonly used as aluminium and iron salts are used as common coagulants. However carbon electrodes have not been investigated as the coagulation properties of carbon are not known.
Table 2. Comparison of performance with different anode and cathode material combinations

\begin{tabular}{|c|c|c|c|c|}
\hline Anode & Cathode & $\begin{array}{c}\text { Initial } \\
\text { COD }(\mathrm{mg} / \mathrm{L})\end{array}$ & $\begin{array}{c}\text { Final } \\
\text { COD }(\mathrm{mg} / \mathrm{L})\end{array}$ & $\begin{array}{c}\text { COD } \\
\text { Removal } \\
\%\end{array}$ \\
\hline $\mathrm{Al}$ & $\mathrm{Al}$ & 305.9 & 147.1 & 51.9 \\
\hline $\mathrm{C}$ & $\mathrm{C}$ & 305.9 & 156.9 & 48.7 \\
\hline $\mathrm{Al}$ & $\mathrm{C}$ & 305.9 & 147.1 & 51.9 \\
\hline $\mathrm{C}$ & $\mathrm{Al}$ & 305.9 & 176.5 & 42.3 \\
\hline
\end{tabular}

Table 2 presents the different combinations of anode and cathode material used and the COD removal efficiencies obtained at the initial COD concentration of $305 \mathrm{mg} / \mathrm{L}$. Higher COD removal efficiencies were obtained when the anode material was $\mathrm{Al}$, irrespective of the cathode material. Marginally lower efficiencies were obtained when carbon was used as the anode material. In all combinations, the $\mathrm{pH}$ change of the final solution was negligible from the initial $\mathrm{pH}$ of 7.7 to $7.4-7.6$ range.

When $\mathrm{Al}$ is used as the anode material, the coagulant is generated from the sacrificial $\mathrm{Al}$ anode while $\mathrm{H}_{2}$ is simultaneously evolved at the inert cathode. The $\mathrm{Al}^{3+}$ hydrolyses, with dynamic changes in the aqueous speciation of aluminium dictating both the coagulant availability and physical form. Initially the $\mathrm{Al}^{+3}$ contribute to charge neutralization of the pollutant particles as isoelectric point is attained. Here a sorption coagulation mechanism occurs resulting in the formation of loose aggregates. As time progresses, further $\mathrm{Al}^{+3}$ addition result in precipitation of amorphous $\mathrm{Al}(\mathrm{OH})_{3}$ that contribute to pollutant aggregation via an enmeshment mechanism. The final stage is pollutant removal where the coagulant aggregates interact with bubbles and are floated to the surface or settle to the bottom of the reactor [12].

It is known that smaller the bubble size, higher the specific surface area and better is the separation efficiency of a flotation process. In addition, larger bubbles can disturb floc settling although it can help to a certain extent the collision frequency required for coagulation. The production of large bubbles in EC is associated with the structure of the electrode. The rougher electrode surfaces of carbon electrodes can provide larger adhering forces to bubbles and therefore produce bigger size bubbles than when using a smooth-surfaced $\mathrm{Al}$ electrode. However, formation of rough electrode surface is inevitable 
due to dissolution of electrodes with continued use. The low COD removal efficiency of carbon electrodes can be attributed to the poor coagulation and flotation effect.

Although the efficiency of removal is marginally low for carbon electrodes, the amount of sludge generated is visibly less due to the absence of metal hydroxide flocs and formation of oxide films that retard removal efficiency is also absent. The separation is primarily due to the flotation and most of the oil remains as a layer on the water surface that could be easily separated. This uncontaminated oil could be used for a secondary purpose in other applications.

\subsection{Effects of electrodes polarity switching}

Passivation of electrodes due to prolong operation and oxide film formation on electrode surface reduce separation efficiency with use. Film formation retard electrode dissolution and therefore reduces coagulation. Such condition reduces the current efficiency of the electrocoagulation process. However conditions that favour or inhibit film formation on electrodes are yet unknown and more research is needed to resolve the above. Switching of polarity may help in prolongation of passivation of electrodes. The effect of electrodes polarity switching on COD removal efficiency is shown in Fig. 5.

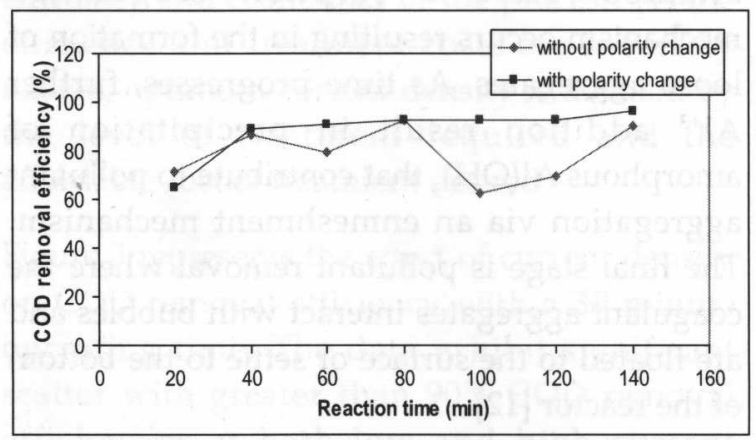

Figure 5: The effect of electrodes polarity switching on $C O D$ removal efficiency

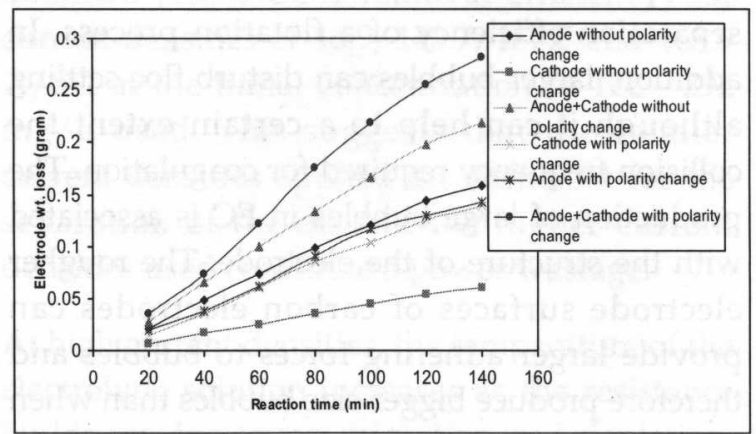

Figure 6: The effect of polarity switching on electrode dissolution
After 20 minutes of reaction time, $64.8 \%$ COD removal efficiency was achieved with polarity change and $71.7 \%$ COD removal efficiency was achieved without polarity change. However with extended operation, electrode polarity change had a consistently high removal efficiency achieving over $90 \%$. The final difference in efficiency for the two modes of operation is marginal. Electrode weight loss data (Fig. 6) show the rapid anode dissolution compared to the cathode with conventional operation and almost equal rate of dissolution of electrodes when the polarity is switched periodically. The total electrode weight loss is higher in the polarity switching mode that partly explains the higher efficiency of the process. Passivation could be the other reason for slower electrode dissolution rate when operated in the conventional mode.

\subsection{Effect of the variation of reactor volume to electrode surface area}

A critical design parameter for $\mathrm{EC}$ is the ratio of reactor volume to the electrode surface area. The effect of the variation of reactor volume on COD removal efficiency is shown in Figure 7 . The reactor volume was changed keeping the surface area of electrodes constant. When reactor volume was $300 \mathrm{ml}$, the COD removal efficiency was highest and it was $100 \%$ for 25.4 $\mathrm{cm} 2$ effective electrode surface area. The highest COD removal efficiency was achieved for 8.5 $\mathrm{m}^{2} / \mathrm{m}^{3}$ of Surface area / reactor volume ratio which falls within the range reported in literature [12]. However, this parameter needs to be optimized for the reactor configuration and operating conditions used for a particular application.

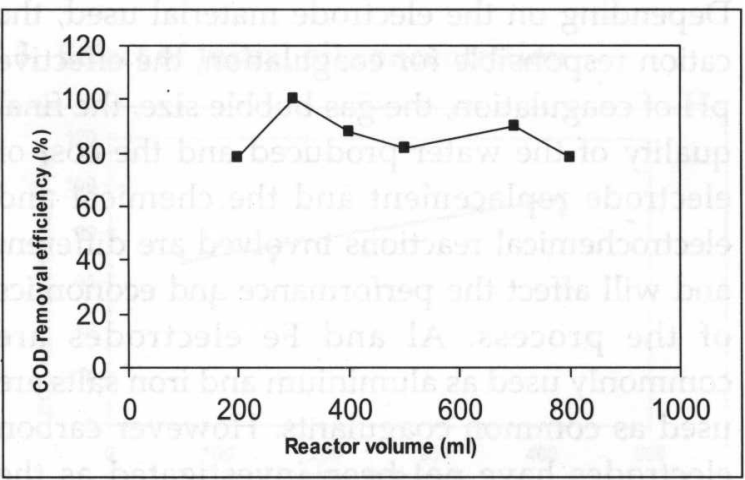

Figure 7: The effect of reactor volume on $\mathrm{COD}$ removal efficiency 
3.7 Effect of electrode spacing

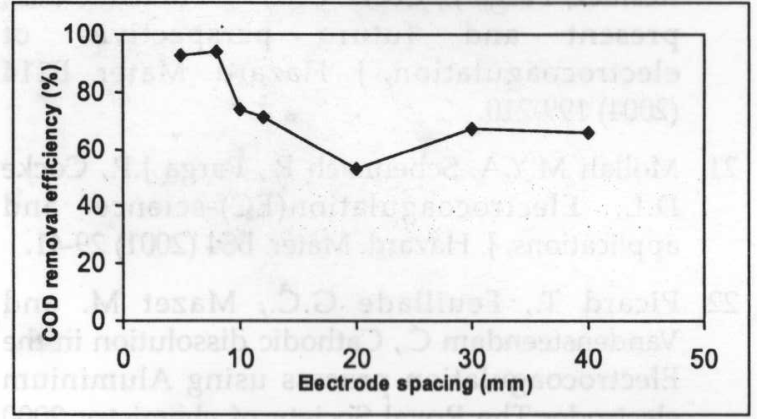

Figure 8: The effect of electrode spacing on $\mathrm{COD}$ removal efficiency

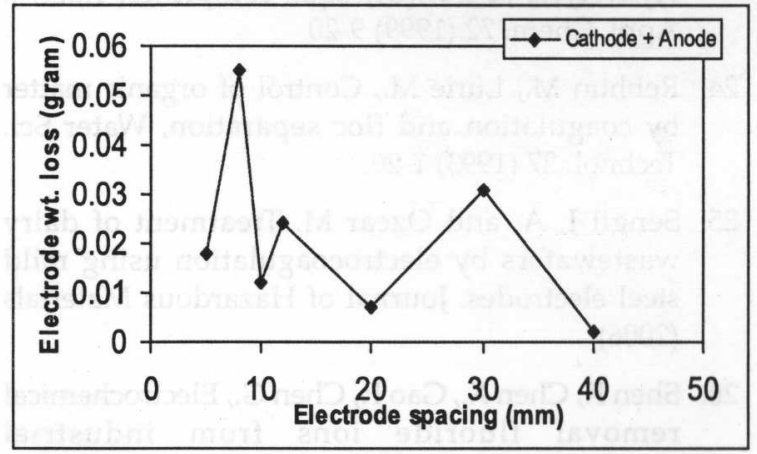

Figure 9: The effect of electrode spacing on weight loss in electrodes

Figure 8 represents the effect of the electrode spacing on COD removal efficiency. To explore the effect of the electrode spacing, the electrode surface area to volume ratio was kept constant at $8.5 \mathrm{~m}^{2} / \mathrm{m}^{3}$.

Over $90 \%$ COD removal efficiency was attained when electrode spacing was less than $10 \mathrm{~mm}$. Above $10 \mathrm{~mm}$ the efficiency dropped below 80 $\%$. According to the results obtained here, the optimum electrode distance was $8 \mathrm{~mm}$. This result is consistent with the observation made in [17] and [28]. The electrode weight loss data (Figure 9.) clearly show the higher rate of dissolution when spacing is $8 \mathrm{~mm}$ and hence the resistance is low. The obtained results help in the design of electrocoagulation reactor cells for effective operation.

\section{Conclusions}

EC was found to be an effective method for the treatment of oily wastewaters. The effects of operational variables such as electrode type, influent $\mathrm{pH}$, current density, initial oil concentration, and design variables such as electrode polarity change, electrode surface area: reactor volume and electrode spacing on performance were examined. A pH close to 4 is suitable when $\mathrm{Al}$ anodes are used and extremely acidic or basic $\mathrm{pH}$ is unsuitable for EC. Current density of $47 \mathrm{~A} / \mathrm{m} 2$ is preferable for having a high COD removal efficiency in 30 minutes. High oil removal efficiencies are obtained for moderate oil concentrations of $300-500 \mathrm{mg} / \mathrm{L}$ as COD. The COD removal efficiency depends on anode material and the removal efficiency was high, when the aluminium electrode was used as anode. Higher COD removal efficiency was achieved with polarity change and COD removal efficiency was highest when surface area / reactor volume was $8.5 \mathrm{~m} 2 / \mathrm{m} 3$ and at 8 $\mathrm{mm}$ electrode spacing. The developed design parameters enable the design of low cost compact treatment units that could be powered by DC sources for effective oil separation from wastewaters.

\section{Acknowledgements}

Authors would like to acknowledge University of Moratuwa for making available funds for this research study. Authors extend their gratitude to Ms. Dinusha Martino, Technical Officer, Environmental Engineering Laboratory of the Department of Chemical and Process Engineering of University of Moratuwa, for her cooperation and technical support in completing this work successfully.

\section{References}

1. American Public Health Association (APHA), Standard Methods for Examination of Water and Wastewater, 17th ed., Washington DC, 1992

2. Ebbing, Darel, Houghton, electro chemistry, 705-707

3. Ford, D., Technologies for removal of hydrocarbons from surface and groundwater sources, Oil in Freshwater: Chemistry, Biology, Countermeasure Technology, (edited by Vandermeulen, J.G. and S.E. Hruey), Pergamon Press. New York. pp. 413-430. 1978.

4. Ashraf Y. Hosny, Separating oil from oil-water emulsions by electroflotation technique, Separations Technology 6 (1996) 9-17

5. Baklan V. Y and Kolesnikova I. P. Influence of electrode material on the electrocoagulation. Journal of Aerosol Science, 27 (1996), 209-210

6. Calvo L.S., Leclerc J.P., Tanguy G., Cames M.C., Paternotte G., Valentin G., Rostan A., Lapicque F., An electrocoagulation unit for the purification of soluble oil wastes of high COD, Environ. Prog. 22 (2003) 57-65. 
7. Can O.T. , Kobya M. , Demirbas E. , ayramoglu M. , Treatment of the textile wastewater by combined electrocoagulation, Chemosphere 62 (2006) 181-187

8. Chen X., Chen G., Yue P.L., Electrocoagulation and electroflotation of restaurant wastewater, J. Environ. Eng. 126 (2000) 858-863.

9. Chen X., Chen G. and Yue P. L. Investigation on the lectrolysis voltage of electrocoagulation. Chemical Engineering Science 57 (2002), 2449 2455.

10. Chen X., Chen G., Yue P.L., Novel electrode system for electroflotation of wastewater, Environ. Sci. Technol. 36 (2002) 778-783.

11. Chen X., Chen G., Yue P.L., Separation of pollutants from restaurant wastewater by electrocoagulation, Sep. Purif. Technol. 19 (2000) 65-76.

12. Holt P.K., Barton G.W., Mitchell C.A., The future for Electrocoagulation as localized water treatment technology, Chemosphere 59 (2005) 355-367

13. Irdemez S., Demircioglu N. and Yildiz Y. S. The effects of $\mathrm{pH}$ phosphate removal from wastewater by electrocoagulation with iron plate electrodes. Journal of Hazardous Materials B137 (2006), 1231 - 1235.

14. Jia-Qian Jiang, Nigel Graham, CecileAndre, Geoff Kelsall H., Nigel Brandon, Laboratory study of Electro-Coagulation-flotation for water treatment Water research 36 (2002) 4064-4078.

15. Khemis M., Leclerc J., Tanguly G., Valentin G. and Lapicque F. Treatment of industrial liquid wastes by electrocoagulation : Experimental investigations and an overall imnterpretation model. Chemical Engineering Science 61 (2006), 3602 - 3609.

16. Kobya M., Hiza H., Senturka E., Aydinera C., Demirbasb E., Treatment of potato chips manufacturing wastewater by electrocoagulation, Desalination 190 (2006) 201-211

17. Mahmut Bayramoglu, Mehmet Kobya, Murat Eyvaz, Elif Senturk, Technical and economic analysis of electrocoagulation for the treatment of poultry slaughterhouse wastewater, Separation and Purification Technology 51 (2006) 404-408

18. Manuel Carmona,, Mohamed Khemis, JeanPierre Leclerc, François Lapicque, A simple model to predict the removal of oil suspensions fromwater using the electrocoagulation technique, Chemical Engineering Science 61 (2006) 1237 - 1246

19. Mehmet Kobya, Elif Senturk, Mahmut Bayramoglu, Treatment of poultry slaughterhouse wastewaters by electrocoagulation, Journal of Hazardous Materials B133 (2006) 172-176
20. Mollah M.Y.A, Morkovsky P., Gomes J.A.G, M. Kesmez, Parga J., Cocke D.L., Fundamentals, present and future perspectives of electrocoagulation, J. Hazard. Mater. B114 (2004) 199-210.

21. Mollah M.Y.A, Schennach R., Parga J.P., Cocke D.L, Electrocoagulation(EC)-science and applications, J. Hazard. Mater. B84 (2001) 29-41.

22. Picard T., Feuillade G.C., Mazet M. and Vandensteendam C., Cathodic dissolution in the Electrocoagulation process using Aluminium electrodes, The Royal Society of chemistry 2000 Vol2, 77 -80.

23. Pykhteev O.Y., Ofimov A.A., Moskvin L.N., Hydrolysis of iron(III) aqua complexes, Russ. J. Appl. Chem. 72 (1999) 9-20.

24. Rebhun M., Lurie M., Control of organic matter by coagulation and floc separation, Water Sci. Technol. 27 (1993) 1-20.

25. Sengil I. A. and Ozcar M. Treatment of dairy wastewaters by electrocoagulation using mild steel electrodes. Journal of Hazardous Materials (2006)

26. Shen F., Chen X., Gao P., Chen G., Electrochemical removal fluoride ions from industrial wastewater, Chem. Eng. Sci. 58 (2003) 987- 993

27. Tezcan U., Una, Uৎgur S., Koparal A.S. Electrocoagulation of olive mill wastewaters, Separation and Purification Technology (2006)

28. Xinhua $\mathrm{Xu}, \mathrm{Xiangfeng} \mathrm{Zhu}$, Treatment of refectory oily waste water by Electrocoagulation process. Chemosphere 56 (2004) 889-894

29. Yousuf M., Mollah A., Schennach R., Parga J. R. and Cocke L. Electrocoagulation - science and applications. Journal of Hazardous Materials, B84 (2001), 29-41

30. Zaroual Z., Azzi M., Saib N., Chainet E., Contribution to the study of electrocoagulation mechanism in basic textile effluent, Journal of Hazardous Materials B131 (2006) 73-78 